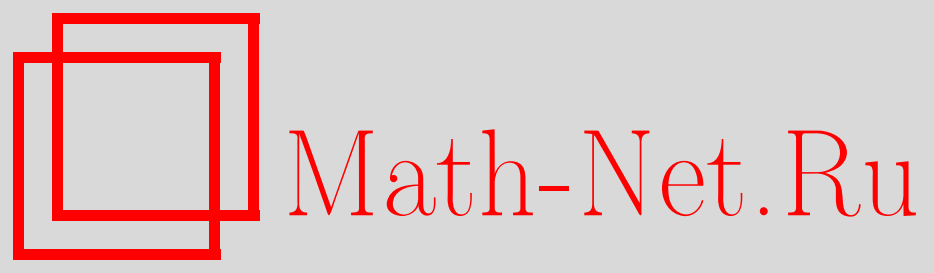

К столетию Владимира Яковлевича Козлова, Дискрет. матем., 2014, том 26, выпуск 2, 3-5

DOI: https://doi.org/10.4213/dm1276

Использование Общероссийского математического портала Math-Net.Ru подразумевает, что вы прочитали и согласны с пользовательским соглашением http://www . mathnet.ru/rus/agreement

Параметры загрузки:

IP : 54.237 .206 .68

26 апреля 2023 г., $13: 26: 47$






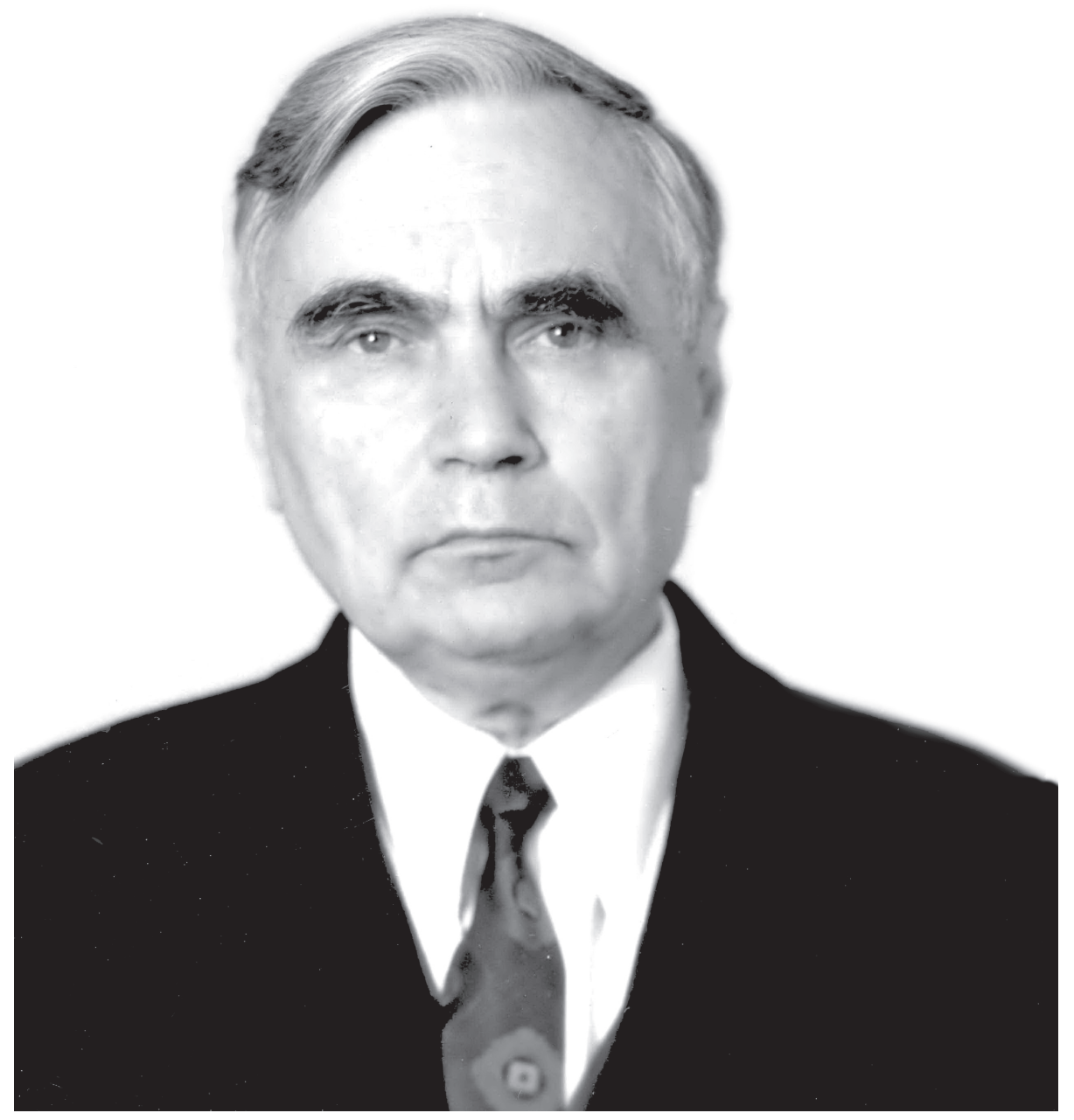

\section{К СТОЛЕТИЮ ВЛАДИМИРА ЯКОВЛЕВИЧА КОЗЛОВА}

28 июня 2014 года исполнилось сто лет со дня рождения известного российского математика и криптографа, члена-корреспондента Российской Академии наук, действительного члена Академии криптографии Российской Федерации, первого главного редактора и одного из основателей журнала «Дискретная математика» Владимира Яковлевича Козлова. 
Владимир Яковлевич родился в Москве в семье служащих. С 1940 по 1951 год после окончания механико-математического факультета Московского государственного университета имени М. В. Ломоносова и аспирантуры он вел преподавательскую работу в Военной Академии бронетанковых и механизированных войск Советской Армии. После защиты докторской диссертации в 1951 году В. Я. Козлов стал профессором механико-математического факультета МГУ.

Научную работу Владимир Яковлевич начал еще в студенческие годы. Его научным руководителем была Нина Карловна Бари, и как ее ученик В.Я.Козлов входит в лузинскую математическую школу. Первая статья Владимира Яковлевича о связях между абсолютной сходимостью и единственностью разложения функции в тригонометрический ряд была опубликована в Докладах Академии наук СССР по представлению академика Андрея Николаевича Колмогорова. За сравнительно короткий срок Владимир Яковлевич получил важные результаты в теории функций и функциональном анализе, в частности, им доказан ряд теорем о тригонометрических рядах, ортогональных и биортогональных системах, базисах в различных функциональных пространствах. В 1956 году Владимир Яковлевич сделал обзорный доклад «Ортогональные и биортогональные системы функций» на проходившем в Москве Третьем Всесоюзном математическом съезде, в этом докладе были подведены итоги развития теории функций, дал анализ последних достижений в этой области и сформулирован целый ряд новых актуальных проблем.

В 1951 году Владимир Яковлевич был направлен на работу в одно из научных учреждений Специальной службы. С этого времени начинается его более чем полувековая плодотворная деятельность в области защиты информации и криптографии. Под его научным руководством и при активном участии были созданы теоретические основы разработки и анализа отечественных шифрующих автоматов и других криптосистем, обеспечивающих защиту секретной информации, передаваемой по различным каналам связи или хранящейся в базах данных.

Неоценимы заслуги В. Я. Козлова в подготовке высококвалифицированных кадров математиков и специалистов-криптографов, в создании отечественной криптографической школы и её научном руководстве. Прямых учеников у него - докторов и кандидатов наук - более 30, во втором поколении (ученики учеников) - около 50. Владимир Яковлевич осуществлял связь Специальной службы с ведущими учёными $\mathrm{AH}$ СССР и её подразделениями.

В.Я. Козлов отдавал много сил научно-организационной деятельности. Наш журнал «Дискретная математика» появился во многом благодаря его инициативе и энергии. Владимир Яковлевич был главным редактором журнала со дня его основания до 2005 года. 
Владимир Яковлевич был одним из инициаторов публикации ежегодника «Труды по дискретной математике», совместного издания Российской Академии наук и Академии криптографии Российской Федерации. С 2010 года продолжением этого издания стал журнал «Математические вопросы криптографии», учрежденный Академией криптографии Российской Федерации и Математическим институтом им. В. А. Стеклова РАН.

Владимир Яковлевич был организатором создания в 70-х годах Отдела дискретной математики в Институте кибернетики им. В. А. Глушкова в Киеве, лаборатории дискретной математики в Московском институте электронного машиностроения и в ряде других мест.

Значительную роль Владимир Яковлевич сыграл в создании, становлении и развитии Академии криптографии Российской Федерации и в повышении эффективности её деятельности.

За большой вклад в отечественную науку и практическую деятельность по защите государственных секретов Владимир Яковлевич был награждён семью орденами и многими медалями, удостоен звания лауреата Государственной премии.

Владимир Яковлевич был обаятельным, глубоко интеллигентным человеком, прекрасным товарищем, собеседником, с большим чувством юмора. До последнего дня отдавал себя делу, которому он служил. Он относился к жизни, к семье, коллегам по работе с большой любовью, его оптимизму и энергии мог позавидовать любой, кто с ним общался. Самоотверженность, увлеченность наукой, честность, искренность, доброжелательность в общении с людьми - вот те качества, которые хранятся в памяти всех тех, кто был знаком с Владимиром Яковлевичем Козловым. 